\title{
Making the Borderland
}

In the fall of 1685, acting upon the Kangxi emperor's (r. 1662-1722) orders, a garrison officer (zhufang xieling), Le-chu, and his men began to survey Changbaishan and to map the topography of the region near the Yalu River. ${ }^{1}$ Their field investigation was part of an ambitious project to create The Unified Gazetteer of the Great Qing (Da Qing yitongzhi). When they approached a place named Sandaogou on the western bank of the Yalu River, they encountered a group of Koreans who had illegally crossed the river and were searching for ginseng. This illicit expedition had been organized by a local Korean official who had assembled a group of thirty-one "vagabonds and wanderers," all natives of Hamgyŏng Province. The Qing officials began to shoot arrows at the illegal intruders to drive them away. This frightened the Koreans, who fired back with their rifles, killing a Qing official and twelve horses and injuring two other people. The Korean intruders managed to escape from the area, but because the Shengjing military governor reported the incident to the Board of Rites in Beijing, the incident soon escalated into a serious diplomatic issue between Beijing and Seoul. ${ }^{2}$

The respective responses of the Qing and Chosorn courts to this incident dramatically illustrate the complexities of the relationship between the two states. Shortly after the incident, the Kangxi emperor's emissary went to Seoul to investigate the case and forced the Choson court to execute all of the offenders and the local officials involved. The Chosŏn king Sukchong (r. 1675-1720) was also asked to write a long and apologetic memorial to the Kangxi emperor and to pay a fine of twenty thousand liang of silver. As a short-term measure to prevent further trespassing for illegal ginseng gathering, the Chosŏn court forbade the Korean tribute embassy from engaging in private ginseng trading during its missions to Beijing 
and banned the ginseng trade with Japan via Pusan. But this was not the end of the matter. The Kangxi emperor's second response came in 1711 in the form of an investigation into the Changbaishan area, a place that traversed the Qing-Chosŏn boundary. The emperor announced:

The Huntong [Sungari] River flows north from Changbaishan, goes northeast alongside Jilin [Chuanchang] and Dasheng Wula, and then meets with the Heilongjiang flowing into [the sea]. All of this is Chinese territory [Zhongguo difang]. The Yalu River flows southeast from Changbaishan, then to the southwest between Fenghuangcheng and Ǔiju and on to the sea. Northwest of the Yalu River is all Chinese territory, and to its southeast is Korean territory [Chaoxian difang]. The Tumen River flows east along the perimeter of Changbaishan, then southeast to the ocean. Southwest of the Tumen is Korean territory; northeast of it is Chinese territory. All of these [boundaries] are already known, but the area between the Yalu and the Tumen is still unclear. ... Now I am sending the Butha Ula superintendent [Wula zongguan] Mu-ke-deng to survey [the area]. . . . You must take this chance to examine the area thoroughly in order to investigate the boundaries and report what you find [wu jiang bianjie chaming laizou]. ${ }^{3}$

The last sentence in the emperor's order suggests that China and Korea were about to start the project of examining their mutual boundary for the first time in their long shared history.

This chapter analyzes the 1712 investigation of Changbaishan from three different perspectives. First, it points out that this survey project initiated by Kangxi was closely related to Qing empire building. After successfully defeating the rebellion of the "Three Feudatories" (Sanfan) in South China and the Zheng family in Taiwan, Kangxi was able to turn his attention north toward Russia, which had been a source of worry to the Qing in Manchuria. Alongside military defense, the emperor also launched a series of projects to research the geographical contours of the empire and lay out its boundaries on maps. The survey of Changbaishan was just one part of this larger plan. Second, this investigation of the northeastern region was also necessary and useful for the purpose of promoting the status of the Manchus in the empire. As the birthplace of the Manchu ancestors, Changbaishan would receive special attention and respect. In addition to political considerations, the natural resources growing in the region's mountains-most notably ginsengneeded to be protected for the imperial court. The emperor had, therefore, every reason to desire more information about this area.

Finally, the process and outcome of the imperial investigation provide excellent evidence of how the Qing and Chosŏn courts understood one another, especially with regard to territories and sovereignty, and how the asymmetrical relationship between them actually worked when they discussed important issues such as boundaries. The Qing court-representing the "great country" — supposed that it controlled the mountains at the boundary with the Chosŏn, whereas the Koreans 
believed that they enjoyed at least partial sovereignty over these same mountains. The area was Golmin šanggiyan alin or Changbaishan for the Manchu emperor, but it was also Paektusan for the Chosŏn royal family. Despite its symbolic significance, both the Qing and Chosŏn courts had only limited geographic knowledge about Changbaishan, largely because of the area's deep forests and tough terrain. When the Qing rulers attempted to clarify the empire's boundaries, especially the area between the Yalu and Tumen Rivers, however, the Chosŏn court fell back on the rhetoric of the age-old tributary relationship to fend them off. As this chapter shows, this rhetoric did not favor the Qing efforts; instead, it allowed the unclear limits of the two neighbors' territories on the upper reaches of the Tumen River to stand, thus creating the Qing-Chosŏn borderland.

\section{QING EMPIRE BUILDING}

Hong Taiji died in 1643, before the Qing armies crossed Shanhaiguan. It was thus his son, the Shunzhi emperor (r. 1644-61), who entered the Ming capital to announce that the mandate of heaven had transferred to the Qing. But although the imperial court settled in Beijing, China was not actually quite conquered. Li Zicheng and other rebels were still alive, and important cities and towns in the north remained in the hands of former Ming commanders or local elites. In the 1640s, the ultimate success of the Qing empire could not have been predicted. However, Prince Regent Dorgon (1612-1650) and a group of commanders and banner officials survived the political intrigues during the early years of the conquest and eventually succeeded in consolidating Manchu power by incorporating Han Chinese officials into the Qing empire. ${ }^{4}$

Domestic consolidation and military stability at the empire's margins were largely achieved during Kangxi's reign, a period that has been considered "not only the longest but also one of the most vibrant and complex in the history of imperial China."5 Holding onto Qing rule, however, required Kangxi to wage a series of wars against domestic rebels and external rivals. The first and the most serious disruption to his rule was caused by the Three Feudatories, who had been given extraordinary powers and enormous domains in southern China as rewards for serving the conquering Qing court in the 1640s and 1650s. In Yunnan, Guizhou, Guangdong, Guangxi, and Fujian, these former Ming soldiers were granted civil and military authority to police, tax, and trade largely outside of Beijing's control. By 1672, the Kangxi emperor determined that the main threat to the survival of the Qing was the independent military power of these Three Feudatories and decided to curtail their power. The most powerful of the three, Wu Sangui, responded to Beijing by revolting, but Kangxi eventually succeeded in defeating the rebels and establishing centralized rule in the south. In addition to the Three Feudatories, Zheng Chenggong, who captured Taiwan in 1661 and supported the Ming cause, 
posed another threat to the shaky foundations of the Qing. The presence of the Zheng family in Taiwan also hampered trade along the Fujian coast as well as in Zhejiang and Guangdong. However, the last members of the Zheng family surrendered to Qing forces in 1683, and Taiwan was finally incorporated into the Qing empire. ${ }^{6}$

Even before defeating these domestic rebellions in South China, the Kangxi emperor had to deal with the northeastern region, where Russian settlers clashed increasingly with Mongol and Manchu residents. He was agitated in particular by the growing number of Russian settlers who promoted agriculture along the Heilongjiang and had won the local tribes around Nerchinsk and Albazin over to their side. Qing armies were dispatched to destroy the Russian settlements at Albazin, but Russia and the Qing court eventually reached a diplomatic solution, resulting in the signing of the Treaty of Nerchinsk in 1689. This important agreement between the Qing emperor and the Russian tsar granted Russians access to Chinese markets but, more importantly, helped the Qing prevent the Zunghar Mongols from making an alliance with Russia. The Zunghar leader, Galdan, had been trained as a lama under the Fifth Dalai Lama and therefore possessed great spiritual authority among the Zunghars and other Mongol tribes. With an ambition for another Mongol empire in the steppe, Galdan began to get involved in rivalries among the Khalkas, thereby posing a serious challenge to Qing rule in Mongolia. Solidifying his position with Russia with the Treaty of Nerchinsk, Kangxi was determined to put an end to Galdan's ambitions. From 1690 to 1697, Kangxi led personal expeditions to defeat Galdan, who died hopelessly surrounded by Qing forces. By the time Kangxi died in 1722, the Qing empire had not yet reached its greatest size, but its boundaries were generally secure, and Manchu rule was firmly established in China. ${ }^{7}$

Qing empire building was envisioned through cartographic investigations that were rigorously promoted by the Qing rulers. ${ }^{8}$ These mapping projects were, in fact, closely linked to the broader context of the rise of powerful and expansionist empires in Eurasia during the seventeenth and eighteenth centuries, when sovereignty was gradually becoming tied to territorial integrity. Before the seventeenth century, the rulers of European and Asian states did not have clearly delimited conceptions of the boundaries of their domains. During the seventeenth century, however, the major states of Eurasia negotiated fixed linear boundaries in order to stake out their territories against competitors. Multiple sovereignties, which allowed small states to pay tribute to more than one neighboring country, became impossible as maps gradually came to demarcate fixed boundaries between states. The Qing emperors shared with the rulers of European empires such as France and Russia a common awareness of the need to establish their territorial boundaries, and like their European counterparts, they used maps as a vehicle to this end. ${ }^{9}$ 
The Kangxi era was a crucial moment in the Qing cartographic and boundarymaking project. As the Jesuits at the Kangxi court recorded in their memoirs, the emperor clearly recognized the potential threat from his neighbors, in particular the future threat posed by the Russians to the Qing empire. ${ }^{10}$ The prospect of a formidable Russian challenge from the north and the repeated defection of nomadic tribes into Manchuria indicated to the Kangxi emperor that there was an urgent need to clarify the empire's territorial limits. It was the lack of a clear boundary in the Heilongjiang region that had led to the conflict with Russia, so resolving the ambiguity of the boundary in that area was an essential precondition of the Treaty of Nerchinsk. This agreement helped the two parties eliminate cross-boundary mobility and fix loyalties along the boundary, forcing local tribes to submit to clearly defined states occupying demarcated territories. ${ }^{11}$

The Kangxi emperor's desire to map the boundaries of his expanding territory was satisfied thanks to the timely arrival of cartographic techniques developed in Europe. When he began to promote his mapping project, he found that some of the Jesuits visiting his country possessed the necessary measurement technology, and he allowed them to accompany him on his northern campaigns against Galdan. Most of the foreign surveyors who participated in map making for Kangxi were from France, Europe's leader in cartography. The first commission for the Jesuit cartographic project was to survey and map the environs of Beijing in 1707. Kangxi was pleased with the results and requested a second survey of portions of the Great Wall in $1708 .^{12}$ Later, when the survey of the whole of the northern Zhili region was completed in 1710 , the emperor finally commissioned the production of an atlas of the entire empire, later known as the Jesuit Atlas or Map with a Complete View of the Imperial Territories (Huangyu quanlan tu). The map was produced in woodblock twice, in 1717 and 1721, and in copperplate in 1719. As Peter Perdue explains, the name of the atlas indicated Kangxi's desire to encompass the entire realm in his gaze: "The compilation of the atlas was just one component of a broader project to systematize and rationalize the ruler's knowledge of space and time." ${ }_{13}$ The Jesuits surveyed the homeland of the Manchus around Mukden, Jehol, and the Ussuri and Heilongjiang Rivers. In fact, many Qing officials, including those who had participated in surveys of the boundaries with the Chosonn, developed technologies for cartographic investigation while working with the Jesuits. ${ }^{14}$

These mapping projects helped the Qing emperors both promote their power within the empire and clarify the territorial limits of the imperial domains. Maps provided better knowledge of the realm and offered concomitant military advantages for conquests as well as for subduing revolts. Since "representing territory cartographically was one way to lay claim to it," the Huangyu quanlan tu defined what China was territorially to the rest of the world. ${ }^{15}$ Furthermore, the Kangxi emperor's mapping of the Manchu homeland was clearly linked to his desire to distinguish Manchu identity from Han Chinese culture. It was intended "to enhance 
Manchu identity by inscribing Manchu place [and] to define the extent of Qing imperial space." ${ }^{16}$ Later, in the mid-eighteenth century, the mapping of the northwestern region helped to systematize and clarify the Qianlong emperor's knowledge of his empire's territory. Therefore, military conquests alone did not complete the process of incorporating new territory into the Qing empire ( ru bantu). As James Millward notes, "Mapping and research into the geography were instrumental in making this area [the northwest] part of a new, expanded conception of China." ${ }^{17}$ In other words, it was the map that completed the process of Qing empire building, in both the northeast and the northwest.

\section{THE QING NORTHEAST AND GINSENG}

The northeastern region carried special meanings for the Qing imperial court. First, the area was the sacred birthplace of the Manchu court. Called the "land from whence the dragon arose" (longxing zhi di), the "cradle of the Manchus" (faxiang zhi di), and the "place of Manchu origins" (genben zhi di), this vital region was considered a reserve for the conservation of Manchu identity, which included martial prowess and nomadic resilience. These were important traits for securing Qing political power and distinguishing the Manchus from other ethnic groups in China. Even after settling in Beijing, the Qing court built an auxiliary capital (peidu) in Shengjing, the old capital of Nurhaci and Hong Taiji-evidence that the Qing rulers gave the northeast significant attention. ${ }^{18}$ Second, it was a geopolitically crucial location for stabilizing the boundary with Russia, pacifying the Mongols in eastern Mongolia, and controlling the Chosŏn in the south. The northeast was also the gateway for entry into China proper and Beijing. The Kangxi emperor's efforts to negotiate the boundary with Russia clearly show this strategic significance of the northeast in the Qing empire. It was also considered the last refuge to which the Qing imperial court could retreat and from which it could defend itself against the Han Chinese. ${ }^{19}$

The Qing court's special concern with the northeast was well expressed in "imperial eastern tours" (dongxun) to the region. Inspecting the realm is an ancient feature of leadership in China, but the practice reached full fruition during the Qing period. ${ }^{20}$ Imperial touring was emphasized, especially by Kangxi, as a useful opportunity to strengthen Qing rule over the domain. Kangxi visited the northeast three times, in 1671,1682 , and $1698 .{ }^{21}$ Despite their official stated purpose of "visiting ancestral tombs and fulfilling filial duty," such tours to the Shengjing area had more important motivations. For the Qing emperors, the sight of a ruler on horseback was a sign of vitality and strength as well as a demonstration of powerful affinity to Inner Asian precedents-evidence of "Qing ethno-dynastic rule," as Michael Chang puts it. ${ }^{22}$ Accompanied by Manchu and Mongol princes, nobles, and bannermen, the emperors often participated in hunting expeditions during 


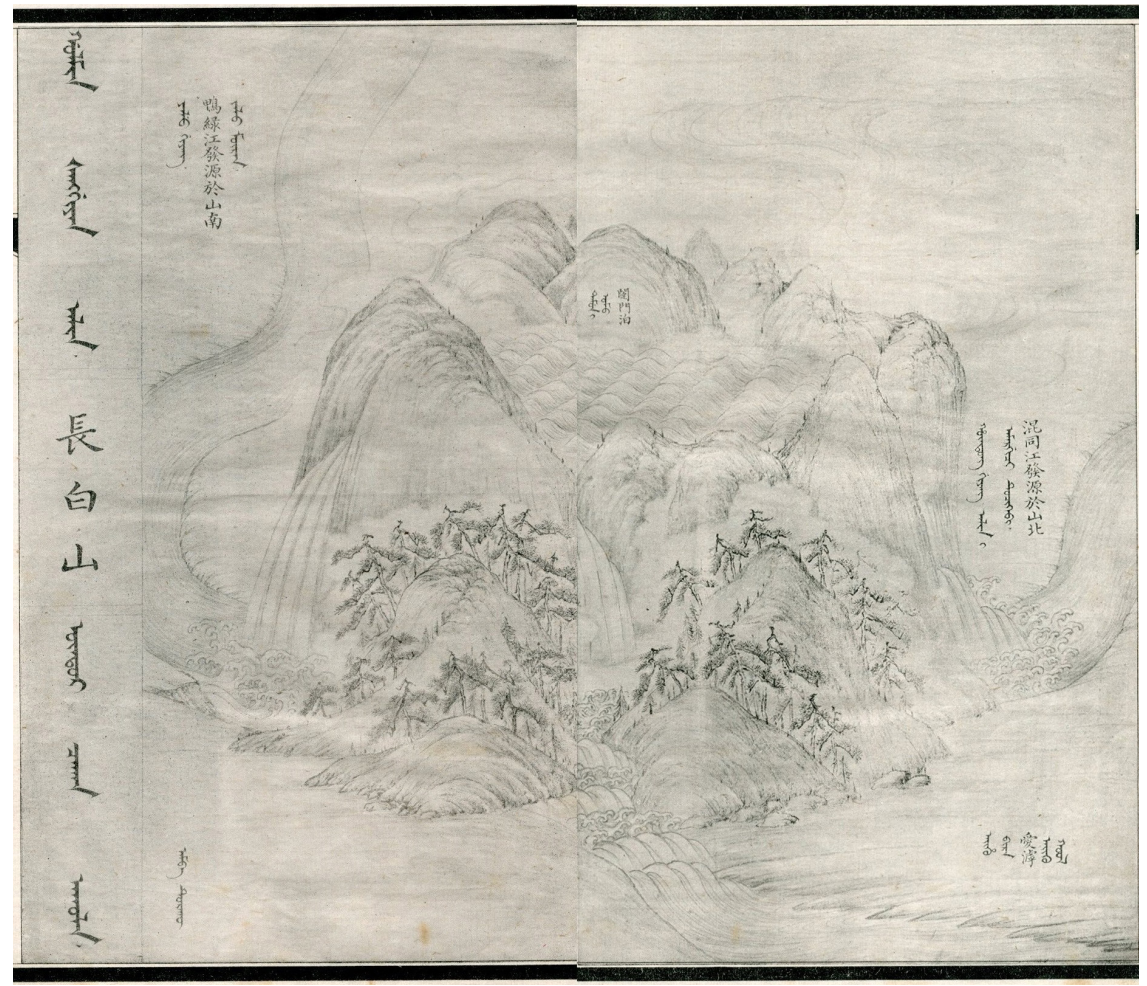

FIGURE 4. Changbaishan. From Manzhou Shilu (Manchu Veritable Record), 1779. Manuscript, $26.2 \times 15.7 \mathrm{~cm}$. Korea University Library. Used with permission.

these journeys. The necessity of coordinating great numbers of people into an entourage and organizing the logistics of encampment made the tours very similar to military campaigns, thereby also providing a good opportunity to check military preparations and improve the martial skills of the bannermen..$^{23}$ The eastern tours were also intended to serve the political interests of the emperor. Kangxi made his first visit to Shengjing right after he took charge of his court in person. For the young emperor, who needed to verify his imperial status to Manchu aristocrats and Han officials, the eastern tours provided a proper occasion to perform the role of the emperor, such as by making sacrifices at the tombs of Nurhaci and Hong Taiji. Conducting this ceremony in the old capital helped connect Kangxi with the ancestors of the dynasty and confirm his political status as the legitimate ruler of the Qing empire. ${ }^{24}$

In addition to their political and military value, the lands of the Qing northeast provided the ruling house with important sources of the imperial court's privy 
revenue. As explained in chapter 1, the rich natural resources of the northeast were a crucial factor in the initial development of the Jurchen state and the formation of Manchu political identity. Once Qing rule was consolidated in China proper, greater emphasis was put on Manchuria, the cultural reservoir of the old and pure Manchu traditions. The Qing policy on Manchuria after the 1644 conquest was not aimed merely at immediate material sustenance, but rather at the purpose of "imperial foraging." As David Bello explains, the Qing court sought to develop a strategy to preserve and promote Manchu cultural identity and military skills in their sacred birthplace. Both hunting and gathering were considered integral elements of a distinct Manchu identity. This Manchu tradition required the Qing court to preserve a separate space isolated from the Han Chinese population, and the northeast provided a perfect location for this project. A great number of imperial estates were built in eastern Fengtian and southwestern Jilin. These enclaved spaces and the practice of imperial foraging in Manchuria are evidence of the Qing strategy to maintain the spatial and cultural conditions for the preservation of the dynasty's pre-conquest ethnic identity endangered by Han acculturation pressures. $^{25}$

Once Qing rule was consolidated in China proper, the court developed a more complicated system of ginseng monopoly. The Imperial Household Department (Neiwufu) took responsibility for providing various natural resources, including ginseng, for imperial demands. The Imperial Household Department was separate from the regular bureaucracy and solely managed the extraction of wealth for the imperial court. It was exclusively staffed by bannermen from the Three Upper Banners (Shangsanqi), namely the Plain Yellow, the Bordered Yellow, and the Plain White, which were directly controlled by the emperor. ${ }^{26}$ Among a number of its subsections, the Office of the Imperial Hunt (Duyusi) was in charge of hunting and gathering of ginseng, pearls, honey, and furs, and provided these tributes to the imperial court. In Manchuria, the Imperial Household Department built two institutions to manage ginseng monopoly: the Shengjing branch of the Imperial Household Department (Shengjing Neiwufu) and the Butha Ula superintendent (Dasheng Wula zongguan). ${ }^{27}$ The Shengjing branch, previously called the bondservant captains of the Three Upper Banners in Shengjing (Shengjing Shangsanqi baoyi zuoling), managed imperial estates and ginseng mountains scattered around in the region. ${ }^{28}$ By 1667 , the Shengjing branch took over responsibility of the ginseng monopoly and dispatched fifty people from each banner to collect ginseng on specified mountains every year, along with officers and soldiers who watched the movements of these collectors. ${ }^{29}$ The Butha Ula superintendent was directly supervised by the Imperial Household Department, even though it was physically located within the jurisdiction of the Jilin military governor. During the mid-seventeenth century, the Butha Ula superintendent was at first a lower official of the sixth rank, but by 1698 it was promoted to the 
third rank, a position being selected by the emperor and inherited for generations..$^{30}$ During the Kangxi era, when the management of imperial foraging in Manchuria became more important for the Qing court, the roles of the Butha Ula superintendent continued to increase. Ginseng mountains (shenshan) as well as battue hunting grounds (weichang), scattered all around from the Sungari and Mudan Rivers to Changbaishan, were under jurisdiction of the Butha Ula superintendent. ${ }^{31}$ Ginseng tribute from Butha Ula was sent to the Imperial Household Department in Beijing, where it was carefully reviewed and divided by quality for imperial usage. ${ }^{32}$ Ginseng management was removed from the responsibility of the Butha Ula only in 1745, when the Qing court established a special office for ginseng management in Shengjing, Jilin, and Ningguta in order to further strengthen the state monopoly of ginseng. ${ }^{33}$

Besides the ginseng management of the Imperial Household Department, the Eight Banners (baqi) had long participated in ginseng gathering. Prior to the 1644 conquest of China proper, the right to hunt and gather pearls, sable pelts, and ginseng was reserved for the Manchu imperial families and their banners. The court announced an equal division of the right to collect ginseng among the eight banners and enforced a prohibition on violations of other banners' allocated ginseng mountains. This practice of dividing ginseng collection among the banners showed that Hong Taiji continued to acknowledge the principle of the equal privileges of the eight banner houses (bajia junfen). ${ }^{34}$ After moving to Beijing, the Shunzhi emperor continued to allocate specific ginseng-producing mountains to each banner and allowed only those with imperial princely rank to dispatch a given number of men to harvest a given amount of ginseng within a designated area. Unauthorized bannermen and civilians were punished if found gathering ginseng. ${ }^{35}$ Cong Peiyuan explains that the ginseng gathering of the Eight Banners differed in some ways from that of the Butha Ula superintendent. While the Eight Banners dispatched a large number of soldiers irregularly, the Butha Ula had a set number of butha soldiers (dasheng zhuangding), who were obliged to pay a given amount of ginseng for the imperial court on a regular basis. The number of soldiers that the Eight Banners and the Butha Ula superintendent dispatched for ginseng gathering was constantly changing depending on their demands. ${ }^{36}$

Systematic ginseng management became particularly pronounced during the Kangxi period. In 1684, the emperor reduced banner privileges for exclusive ginseng gathering by ending the allocation of specific ginseng mountains to each banner. He also limited the number of gatherers and the amount of ginseng permitted for each of the princes and aristocrats, who had to pay taxes at Shanhaiguan for the surplus ginseng that they collected beyond the set amount. ${ }^{37}$ In 1709 the practice of allocating ginseng-producing mountains to the Eight Banners finally ended. This decision shows that by this time the Qing efforts to manage the ginseng monopoly within the framework of the traditional banner organization were failing, because 
TABLE 1 The ginseng-gathering privileges of princes and aristocrats by rank.

\begin{tabular}{lcc}
\hline Rank & $\begin{array}{c}\text { Number of men dispatched to } \\
\text { gather ginseng }\end{array}$ & $\begin{array}{c}\text { Amount of ginseng permitted to } \\
\text { be gathered (jin) }\end{array}$ \\
\hline qinwang & 140 & 70 \\
shizi & 120 & 60 \\
junwang & 100 & 50 \\
zhangzi & 90 & 45 \\
beile & 80 & 40 \\
beise & 60 & 30 \\
zhenguogong & 45 & 22 \\
fuguogong & 35 & 17 \\
huguo jiangjun & 25 & 12 \\
fuguo jiangjun & 20 & 10 \\
fengguo jiangjun & 18 & 9 \\
fengen jiangjun & 15 & 7 \\
\hline
\end{tabular}

SOU RCES: Shengjing shenwu dang'an shiliao, 26 (Kangxi 23/1/24; Kangxi 23/3/17); Imamura, Ninjinshi, 2:224.

wild ginseng was overharvested and rapidly declining, while state regulations to tackle widespread illegal poaching were ineffective. ${ }^{38}$ The court temporarily closed overexploited ginseng-producing areas at the boundaries of Liaoning and Jilin, while seeking to develop new ginseng mountains in northern Jilin and to the east of the Ussuri River. However, the Elmin and Halmin areas in Shengjing were still open every year for ginseng gathering. ${ }^{39}$ Importantly, even after the abolition of banner privileges for ginseng gathering, the Qing court did not ease the prohibition on Han Chinese entering and gathering ginseng in these protected locations. In 1709, the Kangxi emperor warned: "Ginseng has an important use at the court and thus should not be in shortage. Ginseng gathering is allowed for Manchu soldiers but not for Han Chinese. [Illegal Han Chinese ginseng pickers] should be arrested." ${ }^{40}$ Kangxi considered ginseng in Manchuria to belong exclusively to the Manchus, just as his grandfather Hong Taiji had done.

\section{CHANGBAISHAN AND PAEKTUSAN}

Changbaishan, located at the boundary with the Chosonn, was respected as the birthplace of the Manchu imperial family. The mountain was called by different names, including Golmin šanggiyan alin ("long and white") by the Manchus, Changbaishan ("long and white" or "ever-white") by the Chinese, and Paektusan ("white head") by the Koreans. These names stemmed from the fact that the mountain looks white throughout the year because of the snow on its peaks. This phenomenon inspired many folk explanations, such as "The Bodhisattva wears 
white clothes and lives in the mountain"; "The animals living on the mountain are all white"; and "Only white flowers grow on the mountain." It was during the Liao (907-1125) and Jin (1115-1234) dynasties that the name Changbaishan first appeared in Chinese records. The name Paektusan appears in Korean documents from the early Koryŏ dynasty (918-1392).41

Soon after the Manchu rulers rose to power in Liaodong, their strong interest in Changbaishan became apparent. Their respect for the mountain is evident in the following account, which appears on the first page of the Qing Veritable Records of the reign of Nurhaci (Qing Taizu shilu):

Qing Taizu Aisin Gioro [Nurhaci's] ancestors emerged from Changbaishan. It is two hundred $l i$ in height and one thousand $l i$ around. Trees are extremely dense there. On the top of the mountain is a small lake called the Tamun, which is eighty $l i$ in circumference. It is both deep and wide. Three rivers, the Yalu, the Huntong [Sungari], and the Aihu [Tumen] ${ }^{42}$ originate from it. The Yalu River begins on the south side of the mountain and flows west to the sea south of Liaodong. The Huntong River comes from the north side of the mountain and flows northward to the North Sea. The Aihu River flows eastward and enters the East Sea. The three rivers have marvelous spirits, and the pearls produced in this region are highly valuable for generations to come... The mountain named Bukūri in the east of Changbaishan had the lake of Bulhüri, where three daughters from Heaven had come to take a bath. ... The youngest daughter, Fekulen, took a red fruit delivered by a divinely magpie and then became pregnant. Later she gave a birth to a child, whose surname was Aisin Gioro and given name was Bukūri Yongšon. ${ }^{43}$

This passage states clearly that Changbaishan was associated with the origin of the Manchus. The legend of the sacred mountain and its role in the Manchu rise to power thus predated the Qing conquest of China proper. ${ }^{44}$ To Qing rulers, Changbaishan was undoubtedly Manchu territory.

The Kangxi emperor paid special attention to this sacred mountain. In 1677 he sent imperial emissaries led by Umene (?-1690) to investigate Changbaishan and make sacrifices to the mountain. ${ }^{45}$ Such sacrifices became a regular occurrence during the reigns of his descendants. Kangxi even dedicated a poem to the sacred mountain. Along with these rituals, he also elevated the status of the mountain in the geographical hierarchy of sacred mountains to the extent that China's premier mountain, Taishan, was imagined to come from Changbaishan. The Kangxi emperor argued that since Changbaishan was the birthplace of the Manchu imperial court, it should have the highest position among all the mountains in China. Kangxi's interest in this sacred place led him to seek to know more about its environs as well. Surveys of Changbaishan provided an excellent opportunity to promote the eminence of the imperial court; at the same time, geographic information gathered in the northeast could also be used for security purposes. ${ }^{46}$ 
However, mapping the empire's margins required the Qing court to recast its relationships with its neighbors. The problem in regard to Changbaishan was that the Koreans did not think that this mountain belonged to their neighbor. In their vision of a hierarchical order encompassing all Korean mountain chains, Paektusan was quite literally conceived as the summit of the system. The Koreans believed that this mountain accumulated its energy (K. ki) from Manchuria and dispensed it throughout the peninsula. ${ }^{47}$ The high status of Paektusan in Korean geomantic conceptions also contributed to the mystification of the mountain in Korean history, and it has been routinely associated with the rise of the old Korean kingdoms. In his book Lost History of the Three Kingdoms (K. Samguk yusa), Koryŏ’s famous Buddhist monk, Iryŏn (1206-1289), noted that all the founders of Korean kingdoms, including Ko Chosŏn, Parhae, and Koguryŏ, had been born in the Paektusan area. ${ }^{48}$

The northern region surrounding Paektusan had even more significance for the Chosŏn than it had for previous dynasties, as discussed in chapter 1, because the founders of the Chosŏn originated in the region of the Tumen River. Songs of Flying Dragons (K. Yongbi ŏch'on'ga), which celebrates the founding of the Chosŏn dynasty, mentions this area as the birthplace of Yi Sŏnggye's great-grandfather. Hamgyŏng Province, where Paektusan and the Tumen River are located, was the very place in which Yi Sŏnggye built his power through a series of expeditions against the Jurchens. Thus, it was considered "the northern gate of the country" (K. pungmun) and "the place where the king arose" (K. hŭngwang ŭi chi). Like the Qing rulers who treasured their northeastern region, the Chosŏn kings believed that Hamgyŏng Province was their sacred birthplace.

Interestingly, despite the mountain's close connections with the royal family, sacrifices to Paektusan were not included in the Chosŏn court's official list of national rituals until the middle of the eighteenth century. In 1414, when the Chosŏn Board of Rites selected major mountains and rivers in the territory, Paektusan was merely one of the minor mountains to which local officials, not the king, offered sacrifices. ${ }^{49}$ In 1437 , the Board of Rites even proposed an end to the practice of making sacrifices to Paektusan, because "it is not within our country's territory" (K. Paektusan pi pon'guk kyŏngnae)..$^{50}$ The exclusion of Paektusan from the Chosŏn territory is also described in the section on geography in the Veritable Records of the Chosŏn Dynasty (K. Sejong sillok chiri chi) during the Sejong reign (1419-50), which does not list Paektusan as a renowned mountain in Hamgil (Hamgyŏng) Province. Yet this section on geography also mentions that "mountains originating from Paektusan reach to the south up to Choullyŏng," suggesting that Paektusan was the summit and origin of all the mountains on the peninsula. Such ambiguity in the early Chosŏn understanding of Paektusan is also evident in a discussion between the Chosŏn king Hyŏnjong (r. 1660-74) and his court officials. When the king asked whether the mountain was located on Chosŏn land, his officials 
answered, "It is in the foreign land [K. hoji]," but added that "it is also the very summit of our mountains and rivers." ${ }^{11}$ These records demonstrate that during the early Chosŏn period, the northern provinces-Changbaishan and the Tumen River area, in particular-were largely considered to be a place where the Jurchens lived, quite beyond the reach of Chosŏn control..$^{52}$ It was only in the middle of the eighteenth century that the assumption that all of mountains in Chosŏn territory originated from Paektusan was extended to claim that the mountain itself was actually within Chosŏn territory.

During the early Chosŏn period, in fact, neither Paektusan nor Hamgyŏng Province was fully under Chosŏn control. As chapter 1 explained, the early Chosŏn rulers all sought to bring this northern province under Chosŏn rule; nevertheless, this expansionist movement was largely an independent action by the Chosŏn, not the result of an agreement with the Ming. The two neighbors had established a stone marker near the Yalu River in 1605 , but it served to demarcate only a small portion of their boundary. The exact northern limits remained rather unclear. ${ }^{53}$ In addition, access to the region of the six garrisons near the Tumen River, surrounded as it was by mountain ranges, was very limited for both the local population and the central administration. And the region projected northward toward Jurchen territory, making Chosŏn military control nearly impossible. Given the harsh environment and limited access, only a few groups of people settled in Hamgyŏng Province, a situation that led the Chosŏn court to virtually abandon its northern region. ${ }^{54}$ Another reason for the isolation of Hamgyŏng Province from the central politics of the Chosŏn kingdom lay in its cultural affinity with the Jurchens, who had intermingled and intermarried with their Korean neighbors. In the eyes of Seoul, Hamgyŏng Province was beyond the reach of civilization. It was not only geographically remote but culturally foreign as well. 55

From the sixteenth century onward, the stability of the Chosŏn northern region was more closely dependent on the actions of the Jurchens and, later, the Manchus. During the Japanese invasions of 1592-98 and the subsequent struggles for restoration, the Chosŏn court could not afford to pay attention to the north. The northern region, especially P'yŏngan Province, was devastated by Hong Taiji's campaigns against the Chosŏn in 1627 and 1637, when Manchu forces passed through and pillaged the area. Hamgyŏng Province was also insecure and vulnerable; a number of Warka, Hūrha, and other Jurchen descendants who had lived around the Tumen River area for generations, often called the subordinate barbarians of the Chosŏn, had been relocated to Liaodong and mobilized into the eight banner forces. During the years of Nurhaci and Hong Taiji, Manchu troops continued to attack the local tribes near the Tumen River and moved many of these populations to the Manchu center, an action that made the Chosŏn northeastern margins even less populated. ${ }^{56}$ However, the Chosŏn court was not yet given a chance to begin the national project of rebuilding the northern region. What was 
required first was removing any Qing doubts about the Chosŏn court's loyalty and normalizing its relationship with the suzerain power. With the relationship with the Qing still tense, the Chosŏn court could not risk allowing the growth of permanent settlement in the Hamgyŏng Province.

In fact, by the late seventeenth century, when the Three Feudatories revolted in South China and the Mongol prince Buruni attacked Mukden, Qing power in China still seemed precarious to Chosŏn Koreans. News of civil wars in China led the Koreans to anticipate the fall of the Qing court. The Chosŏn court had been concerned about the possibility of political disorder in China and the subsequent threat posed by the retreating Manchus. The Koreans commonly believed that foreign conquerors could not control China proper for more than one hundred years. These expectations, based on historical observations, were confirmed by the breakout of the Three Feudatories' rebellion, which convinced the Koreans that the Qing was in danger of imminent collapse. Koreans believed that in the event of a dynastic collapse, the Manchus would retreat to their homeland in the northeast and eventually invade Chosŏn territory again..$^{57}$

News of the rebellion of the Three Feudatories strengthened the Chosŏn court's hostility toward the Manchus. Some court officials were empowered to call for aggressive action against the Qing, and they welcomed the revolt in South China as an opportunity to take revenge on the Manchus: "The uprising of Wu Sangui is so righteous that we should take advantage of it to clear the disgraceful experience of the invasion [of 1637]. Therefore, how could we dare to dispatch forces to help [the Qing] repress [the Three Feudatories]!" ${ }^{8}$ Tribute emissaries who had visited Beijing and Shengjing also delivered news of the Qing domestic crisis to Seoul. In 1682, Yun Ije, returning from his emissary service in Beijing, reported to King Sukchong:

In Shengjing, there were well-prepared city walls and a numerous population. However, the city gates in Beijing and the main hall [Taihedian] of the palace have crumbled and have not been repaired. It seemed to me that [the Manchus] are planning to retreat, so they do not care about the regions inside [Shanhaiguan] and instead pay attention to the areas around Shengjing and Ningguta as their base. Therefore, their claim to pacify the south is not trustworthy. ... I was also told that the [Kangxi] emperor is going on a massive hunting expedition in Xifengkou, despite his brother's dissuasion. This hunting trip is apparently aimed at displaying Qing military power to the Mongols. ${ }^{59}$

He further quoted the Qing interpreter Li Yishan: "A very difficult situation is coming soon." Yun's report worried Sukchong: "If the Mongols become powerful, the world will be in chaos. How can we be sure that the Chosŏn will be safe?"60

Amid such uncertainty about the future of Qing authority in Beijing, the Chosŏn court could not consider its northern region. Until Manchu rule in China was stabilized and the relationship with the Qing secured, discussions 
about population resettlement or economic development in P'yŏngan and Hamgyŏng Provinces would be difficult. ${ }^{61}$ In fact, only the lonely voice of Nam Kuman (1629-1711) claimed the importance of defending the Yalu and Tumen Rivers. Based on his experience as governor of Hamgyŏng, Nam argued that an effort to protect the northern margin (K. pyŏnji) would be a better strategy for the state's security than would building more defense facilities near Seoul. $\mathrm{He}$ also rejected the idea that the Manchus would retreat to the northeast via the Chosonn north in the event that they had to leave China proper; he found it more reasonable to expect the Manchus to take familiar routes from Shengjing to Ningguta instead of using unknown roads in a foreign country. Thus, he argued that the Chosŏn should develop the northern region:

We have not planned to build garrisons even on lands that our records indicate belong to the Chosonn; we have simply abandoned them to grow rich forests where no one lives. There are only vicious people who come and go illegally to poach ginseng, but nobody can control them. It is to be regretted that court officials, who worry only about trespassing, do not understand that deserting the land is a more serious problem. ${ }^{62}$

In response to Nam's strong arguments for the development of the northern region, the Chosŏn court made a short-lived effort to reopen garrisons near the Yalu River and to encourage people to settle there in the 1670 . However, this reopening was soon canceled. The majority of Chosonn officials were worried that any development of the northern region would cause more trouble. Specifically, they feared that road building in the north would help enemies invade the country, and population settlement along the Yalu and Tumen Rivers would loosen security and cause more people to trespass. In 1685, when reports that local Koreans were illegally crossing the Yalu River reached the Chosonn court, the court immediately closed the roads and garrisons in the area. Chosonn access to its northern margins had to wait until its relations with the Qing were settled.

\section{THE INVESTIGATION OF THE MOUNTAIN}

In addition to his political and historical interest in Changbaishan, Kangxi had another urgent motive for launching an investigation of the Qing-Chosonn boundary: Koreans continued to cross the rivers and illegally enter Qing territory. Chosŏn court records include numerous cases of Korean trespassing and subsequent discussions with the Qing authorities about the repatriation of the offenders. The Qing emperor frequently sent emissaries to Korea to research the situation and to deliver letters ordering the Chosonn to control its boundaries more effectively. Once in Seoul, the Qing officials joined the Chosonn king and court officials in examining the criminals, deciding their sentences, and reporting the 
cases to the Qing emperor, who finally authorized the punishment. ${ }^{63}$ As QingChosŏn relations gradually settled by the 1660 s, Beijing sent imperial emissaries to Seoul less frequently than before. If the number of trespassers was small, the Qing allowed the Chosonn to investigate the cases on its own and to report back to the Qing afterward. Punishments of local officials in charge of the regions in question were also lightened. Harsh sentences, such as that meted out in the 1647 case in which a Qing emissary pressured the Chosŏn court to decapitate a local official for overlooking trespassing in his jurisdiction, ${ }^{64}$ were generally replaced with demotion or dismissal. Sentences for trespassers were often reduced through imperial amnesty. ${ }^{65}$

Not surprisingly, the Chosŏn court sought to avoid conflict with Beijing caused by Koreans crossing illegally into Qing territory. Regardless of how lenient the Qing became toward the Chosŏn, trespassing cases involving Korean subjects always brought trouble for Seoul. The Chosŏn court was especially keen to avoid the presence of Qing officials in Korean territory, since military facilities and strategic locations could be easily exposed during the latter's investigatory visits. All the court could do was to impose heavy sentences on trespassers and hope to avoid incurring Qing criticism. In 1672, the Chosŏn court decided that individuals convicted three times of trespassing should be decapitated, but in 1686 it strengthened the regulation so that all first convictions would lead to beheading on the shore of the Yalu River. A complete prohibition of any ginseng gathering was imposed to stop people from trespassing; this law was included in The Supplement to the National Code (K. Sok taejŏn) published in $1746 .{ }^{66}$

Among the numerous trespassing cases, the Sandaogou incident of 1685, in particular, demonstrates how the Kangxi emperor understood Qing-Chosŏn relations. The emperor was already quite suspicious of Chosŏn loyalty to the Qing, as shown in his decision to impose a heavy fine of twenty thousand liang of silver on the Chosŏn king for neglecting his duty to prevent his people from crossing the Yalu River. In fact, the Ming court had had the same system of fines in place but had applied it only to domestic subjects, never to the Chosŏn king. ${ }^{67}$ The Kangxi emperor's unusually rigorous attitude toward the Chosŏn was closely linked with his awareness of the fact that the Chosŏn court was informed of the rebellion of Three Feudatories and that anti-Qing sentiment consequently resounded in Korea. The Kangxi emperor and his Manchu officials believed that the Chosŏn was disrespectfully anticipating the decline of the Qing dynasty and even considering the possibility of cooperating with anti-Qing forces, such as the Zheng family in Taiwan. Qing suspicion and distrust of the Chosŏn was apparent in 1679, when Korean emissaries were criticized for disregarding the appropriate formalities in writing letters to the emperor. ${ }^{68}$ The Chosŏn king was eventually fined ten thousand liang of silver for the errors in his letter, a decision announced soon after the final defeat of 
the Three Feudatories in order to send a strong warning to the Chosonn court. ${ }^{69}$ Later, in 1683 and 1685, Kangxi refused to accept the petition of the Chosŏn for temporary closure of the regular trading markets in Chunggang (C. Zhongjiang), Hoeryŏng, and Kyŏngwŏn, expressing his suspicions of the Chosŏn: "In controlling foreign countries, there should be a balance between rigorousness and coaxing. The Koreans are naturally cunning and often lie. If we accept their petition now, they will nag endlessly in the future." ${ }^{70}$

After the Sandaogou incident, Kangxi decided to launch his investigation of Changbaishan and the surrounding territories. He first asked the Chosŏn court to participate in a joint survey in 1691, because he knew that an investigation of the mountain could not possibly proceed without the cooperation of local Koreans. In his letter to the Chosŏn king, the emperor explained that he wanted to compile a comprehensive gazetteer ( $\mathrm{Da}$ Qing yitongzhi), but that the records held in Shengjing and Ningguta were all inaccurate. He wrote, "Since the areas south of Uiju and the Tumen River all fall within Chosŏn territory, there must be local people familiar with the boundaries [jierang difang]. . . . [The Chosŏn court] should find such locals and prepare postal stations to receive the Qing imperial emissaries." ${ }^{71}$ When he was told that all Chosŏn roads from Uiju to Changbaishan were closed and inaccessible to both people and horses, the emperor reprimanded the Chosŏn king for his reluctance to participate in the investigation: "Our officials used to see your patrols in the Changbaishan region while they were surveying the land. How is it possible that the Chosŏn has no local people familiar with the boundaries?"72

The Qing opportunity to press the Chosŏn court into cooperating with the investigation finally came in 1710, when Yi Manji, a Korean from Wiwŏn, P’yŏngan Province, illegally crossed the Yalu River, killing and injuring Qing merchants and stealing their ginseng. The Kangxi emperor immediately asked the Chosŏn embassy in Beijing about the area where the incident took place and about the distance of Wiwŏn from Qing territory. In 1711, the emperor announced the dispatch of an imperial emissary to the Chosŏn to investigate Changbaishan and its surrounding areas:

You have my order to survey the area with Chosŏn officials, following the river to reach [the mountain]. You can go by way of Chinese territory [Zhongguo suoshu difang]. If Chosŏn officials are accompanying you in Chinese territory, they, too, can go. If Chinese territory is too rough to traverse, you can enter Chosŏn territory. You must take this chance to examine the area thoroughly in order to investigate the boundaries and report what you find..$^{73}$

However, the Kangxi emperor's proposal for a joint survey of Changbaishan was not welcomed at the Chosŏn court. For the Koreans, repeated visits to Changbaishan by Manchu officials, and their survey of the boundaries, seemed 


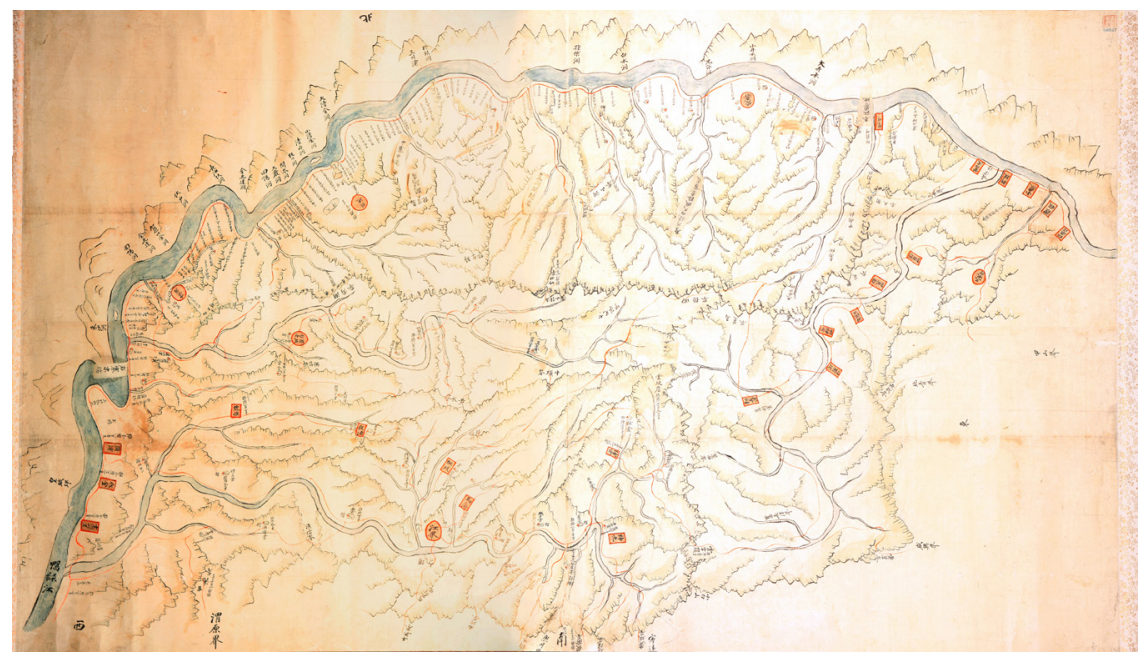

FIGURE 5. P'yesagundo (map of the Four Closed Counties), early nineteenth century. Manuscript, $115 \times 194.5 \mathrm{~cm}$. Kyujanggak Institute for Korean Studies of Seoul National University, no. ko-pok-ch'uk 4709-94. Used with permission.

to presage the possibility of an impending Qing retreat. Korean suspicions of the Qing interest in the boundary had been expressed already in 1680:

King Hyojong (r. 1649-59) once remarked that the Manchus would surely be attacked by the Mongols along the route to Shenyang, so they will try to find their way via Korean territory, crossing through Ǔiju, Yangdŏk, Maengsan, and Hamgyŏng Province to enter their old bases. ... [The Manchus] will seek their path of retreat through our territory to return to their original place. This is why they inspect the area under the excuse of sacrificing to the mountain, ask us to build roads, and claim the land south of Changbaishan as their territory. If they are defeated, they will, by necessity, return to their homeland via our territory. ${ }^{74}$

Given such suspicions at the Chosŏn court, it is understandable that the Kangxi emperor's request for a joint survey in 1691 was not well received. While the Chosŏn court refused to help the Qing investigate the boundary, it was also very careful not to leak any domestic information to its neighbor. In 1698, when a Qing official from Ningguta tried to investigate the area near Kyŏngwŏn and Hoeryŏng and succeeded in mapping the locations of cities and towns, the Chosŏn court decapitated the two interpreters who had cooperated with the Qing official on the project. This practice later became law: anyone who informed foreigners about the condition of roads in Korea would be sentenced to death. ${ }^{75}$ 
The Chosŏn officials were suspicious of the Kangxi emperor's motives for proposing the joint investigation. As one of them angrily complained, "If they just needed geographical information for compilation of a comprehensive gazetteer, it would have been much easier to ask us to investigate the area and draft a map. Why would they bother to send so many officials and to travel inside another country's territories by themselves? . . They are cheating us with some excuses." ${ }^{6}$ In fact, the Qing court clearly stated that the investigation would not violate Chosŏn territory. The Kangxi emperor's letter to the Chosŏn court in 1712 stated that the proposed survey aimed to examine the boundaries from the Qing side and would not bother the Chosŏn. Only in cases when the roads in Qing territory were too arduous to travel would the Qing officials ask for help from the Chosŏn court. ${ }^{77}$ However, these assurances did not relieve Korean anxiety about the Manchu court's intentions. While waiting for the imperial emissary charged with undertaking the investigation, the Chosŏn court decided to refuse all requests for information about the Chosŏn northern region. Instead, it sought to convince the Manchu official, as well as the Qing emperor, that the Yalu and Tumen Rivers served as the boundary between the Qing and the Chosŏn and that "all the territory south of the rivers is ours." 78

\section{MU-KE-DENG'S MISSION}

Although Jesuit missionaries had been involved in other mapping projects carried out by the Qing court, they could not participate in the Changbaishan survey. The Kangxi emperor, who had an understanding of Korean sensitivities, knew that as Westerners they would never have been allowed into Korea. Therefore, the map of the boundary with the Chosŏn had to be filled in by Butha Ula superintendent Mu-ke-deng, a Manchu official who was accompanied by a Chinese mathematician and a surveying team trained by the Jesuits. ${ }^{79} \mathrm{Mu}$-ke-deng's first attempt to investigate Changbaishan, which took place in 1711, faced carefully designed obstruction by the Chosŏn court and local officials. All the Koreans with whom Mu-ke-deng dealt endeavored to discourage the Manchu official from undertaking the dangerous journey to the mountains and refused to cooperate with the survey: they misguided him to more difficult paths and declined to provide proper information about their country. On his first visit, Mu-ke-deng thus failed to achieve his mission, succeeding only in having his front teeth broken. ${ }^{80}$

In 1712, Mu-ke-deng made a second visit to Ǔiju, telling the Koreans that his visit was authorized by an imperial edict and that he had been sent to demarcate the Qing-Chosŏn boundary. This mission was, he declared, designed to "prevent vicious people from disturbing the boundaries." ${ }^{81} \mathrm{He}$ also asked the local Korean official, Pak Kwŏn, whether the latter's office had any documents 
or information related to the location of the boundary and whether military guards were stationed to the south of Changbaishan. The official answer to all of these questions was no. ${ }^{82}$ When Mu-ke-deng began his survey, Pak Kwŏn, his Korean counterpart, could not keep pace with him and eventually abandoned the project. Pak suggested to $\mathrm{Mu}$-ke-deng that marching up the steep side of the mountain through the heavy underbrush and forest was too arduous and that they should engage interpreters and locals instead of doing the work themselves. However, Mu-ke-deng insisted on taking this route. ${ }^{83}$ Assisted only by his Korean interpreter, Mu-ke-deng was able to map the course of the Yalu River quickly, because he traveled against the current of the river. The mouth of the Yalu was wide, and the river narrowed toward its source at the top of the mountain, making it easier to follow the river from the mouth to its source. Traveling the other way was substantially more difficult, because the river disappeared underground or divided from time to time. Because he started his investigation of the Tumen River from the top of Changbaishan, Mu-ke-deng found it difficult to identify the river's actual source. He eventually selected a spot and ordered a stone marker to be erected to mark the watershed from which the Tumen flowed east. The stone marker reads as follows:

The Great Qing Ula superintendent, Mu-ke-deng, received imperial orders to survey the boundary. From this marker to the west is the Yalu River, and to the east is the Tumen River. Therefore, here at this watershed is a stone marker, which was erected and inscribed on June 18, 1712 [Kangxi 51/5/15]..$^{84}$

Besides erecting the stone stele, Mu-ke-deng asked Chosŏn officials to build fences to make the boundary visible. In fact, the Tumen River flowed underground for several dozen $l i$ from its watershed, eventually becoming a wide, easily crossable stream for a distance of about one hundred $l i$. In order to prevent confusion and trespassing, Mu-ke-deng emphasized that the Koreans should decide how to guard their side of the boundary. ${ }^{85}$ Before leaving for Jilin the following month, Mu-ke-deng sent a copy of his map of Changbaishan to the Chosŏn king Sukchong. Later, Sukchong praised the Kangxi emperor for his efforts to demarcate the boundary: "Last summer, the imperial emissary demarcated the boundary without asking for any help from foreigners [the Chosŏn]. Imperial virtue prevented dishonest people from disturbing the boundary. Our small country's king and people altogether appreciate your great kindness. .. . [You] made the river the boundary, marking the north and the south of the mountain." 86

The following year, in 1713, Mu-ke-deng visited Seoul. He asked Sukchong for maps of Changbaishan as well as a general map of Chosŏn. ${ }^{87}$ The king and court officials obviously did not want to share detailed information on the geography of their country with the Manchu official, but they nonetheless had to find a way to 


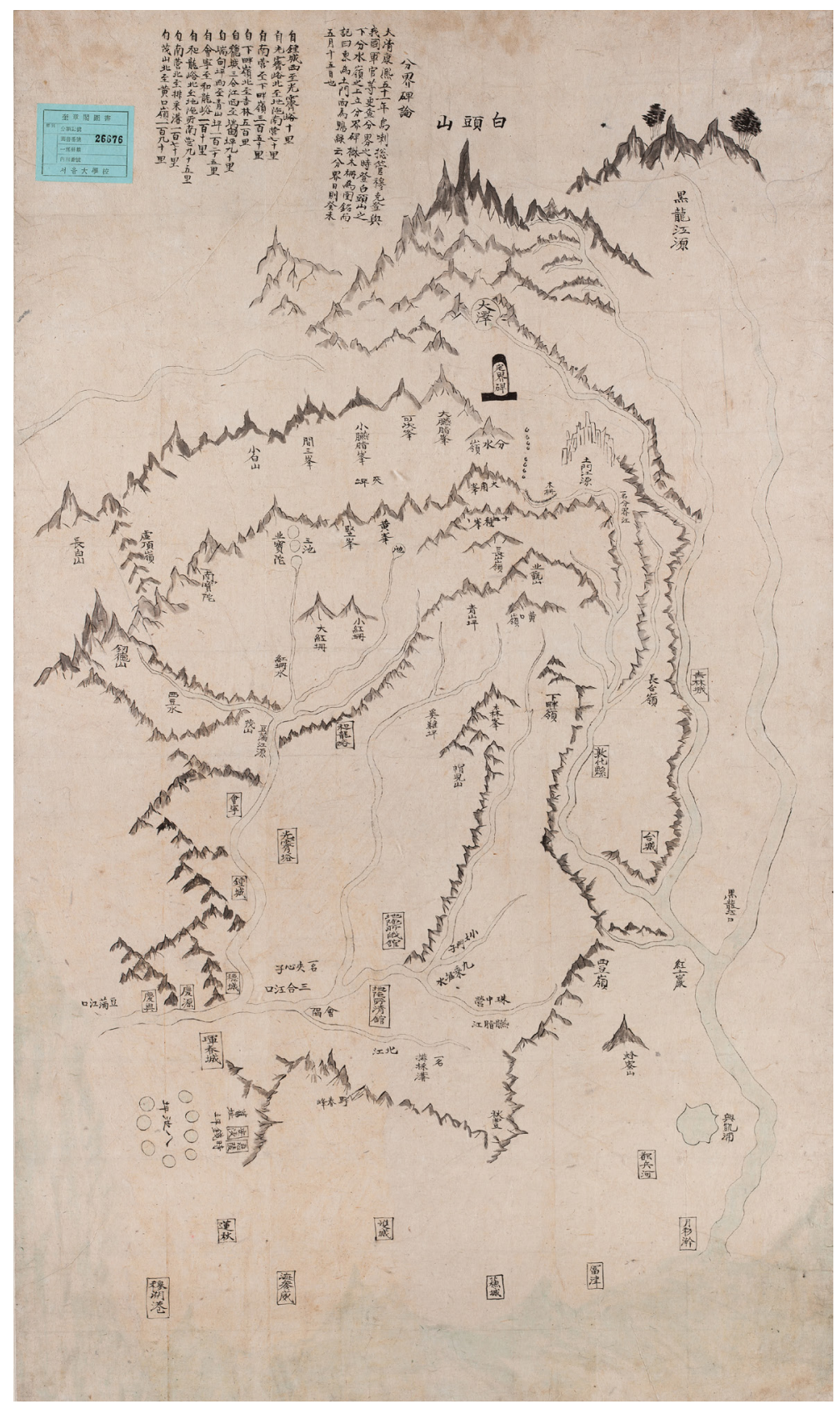

FIGURE 6. Paektusan chónggyebi chido (map of the stele of Changbaishan), date unknown. Manuscript, $97.6 \times 56.9 \mathrm{~cm}$. Kyujanggak Institute for Korean Studies of Seoul National University, no. kyu 26676. Used with permission. 
convince the Qing emissary that the Chosŏn was willing to comply with the imperial order. The Chosŏn supreme councilor (K. yŏngŭijŏng), Yi Yu, informed the king: "Although the nation's defense maps are too detailed, we have just acquired a map that is neither too precise nor too general, with many mistakes on the Paektu rivers. Let us show him this." ${ }^{88} \mathrm{Mu}$-ke-deng made copies of this map, saying, "We are taking one copy with us, and leaving one with you, so that our name and fame can spread to this place." ${ }^{89}$ With this third visit to the Chosŏn, Mu-ke-deng's official mission was complete.

Mu-ke-deng's long, strenuous mission did not, however, resolve all of the boundary issues between the Qing and the Chosŏn. To the contrary, it opened up a new dimension in their ongoing debate. The primary question concerned the location of the Tumen riverhead. After Mu-ke-deng's departure, the Chosŏn officials charged with building wooden fences along the Tumen River found that the spot Mu-ke-deng had identified as the river's origin was, in fact, to northeast of the river and thus incorrect. The Chosonn court faced a dilemma: if it followed Mu-ke-deng's guidelines, fences would be built in the wrong place, in Qing territory. However, if it ignored the Manchu official's findings and erected the fences at its own discretion, this would create problems in its relationship with the Qing court. If the Qing emperor received word that $\mathrm{Mu}$-ke-deng had made a mistake in identifying the Tumen riverhead, the Manchu official could be in trouble. If the Qing court decided to dispatch another official for reexamination, the Chosŏn could face another round of investigation and eventually lose its territory. ${ }^{90}$ After much discussion, the Chosŏn court decided to explain the difficulty of building and maintaining the fences along the boundary to Mu-ke-deng, not to the Qing emperor..$^{91}$ The Chosorn court thus sought to protect its territory by convincing the Manchu official of its perspective, without agitating the Qing emperor.

The Qing court's attitude was very different from that of the Chosonn. There is no evidence that the Kangxi emperor or his successors ever verified the location of the stone marker, a fact that was revealed during boundary surveys in the late nineteenth century and eventually undermined the legitimacy of it as a verification of demarcating the two territorial realms. Instead, Mu-ke-deng was seemingly untroubled about his designation of the Tumen riverhead and its subsequent effect on Qing territory. When Korean interpreter Kim Chinam asked for a copy of the map of Changbaishan, Mu-ke-deng generously answered, "It would be impossible [to give a copy of the map to you] if [the mountain were in] the great country's territory, but because it is in yours, it is not difficult [to give you a copy]."92 In addition, after choosing the location for the Tumen riverhead, Mu-ke-deng stated, "The spot was located ten $l i$ further north than you Koreans thought, so the Chosŏn actually gained more territory." The Koreans 
accompanying Mu-ke-deng were delighted to hear this and no longer doubted his decision about the site of the stone marker. ${ }^{93}$

Later on, Mu-ke-deng reassured the Chosŏn that it need not worry about the location of the marker and noted that he would not survey the mountain again. He added that local Koreans should not bother to build the fences during the busy harvest season. ${ }^{94}$ In fact, when Mu-ke-deng visited Korea the following year, he did not mention the location of the Tumen riverhead at all. The Chosorn court soon realized that the Qing did not care about the location of the stone marker as much as the Chosŏn did. A year after Mu-ke-deng's survey, a Chosŏn official, Hong Ch'ijung, found that Mu-ke-deng's stone marker was very small and not firmly positioned. Even the characters inscribed on it were wrong. Hong observed that this "shows that even though he was an imperial emissary, Mu-ke-deng did not do his best." ${ }^{95}$ Because of the apparent indifference of the Qing, the Chosorn side had no reason to bring up the issue of the Tumen riverhead again. After all of the investigations and discussions, the origin of the Tumen River-the actual location of the Qing-Chosŏn boundary-still remained unclear.

We can find more than "Mu-ke-deng's ignorance and Kangxi's negligence" ${ }^{96}$ in the investigation of Changbaishan and in the ambiguity regarding the Tumen riverhead. The events and circumstances surrounding this survey reveal the uniqueness of the tributary relationship between the Qing and the Chosŏn. Contravening conventional assumptions about the submissive attitude of an inferior tributary state, the Chosŏn court did not passively welcome the Kangxi emperor's proposed joint survey of the mountain. The Koreans were suspicious that the Qing court intended to force them to yield territory to China. Significantly, their concerns about Qing encroachment into Korean territory were closely related to antiManchu sentiment. Since the "Manchu barbarians" had conquered China proper, the Koreans believed that civilization had been lost or greatly compromised in China. They further believed that civilization should be protected from the barbarians and transferred to the Chosŏn. The Koreans did not completely accept Manchu supremacy, even though they fulfilled all of their obligations as a tributary state to the Qing empire. ${ }^{77}$ Therefore, instead of following the norms of a tributary state during the Changbaishan investigation, the Chosŏn officials deliberately hampered Mu-ke-deng's mission and declined to help him. As Andre Schmid says, "The Chosŏn court displayed a subdued defiance of the wishes of the Kangxi emperor," which gives us good evidence to challenge "the Sinocentric image of [the Chosŏn as] a dependent and loyal vassal state."98

By contrast, the Qing court adopted a different approach toward its territorial boundary and political relationship with the Chosonn. For the Kangxi emperor and his emissaries to the Chosonn, the exact location of the Tumen's source or, indeed, the exact limits of the empire's territory were not as crucial as they were for their 
Korean counterparts. The Qing seems to have felt that the surveys of Changbaishan signified Qing suzerainty over the Chosŏn. As the dominant power, the Qing believed that the imposition of imperial authority was sufficient to maintain the proper relationship and clarify the boundaries between the empire and its tributary state. The presentation of imperial virtue and power, rather than the demarcation of clear territorial boundaries, was the important issue. The great country did not need to quibble with a small neighboring state over a few dozen $l i$ of land. The location of the boundary on the upper Tumen River remained unclear, but the imperial authority was not compromised at all. The Chosŏn court joined the Qing-initiated survey, but the Koreans managed to protect their territory by not clarifying the boundary at the Tumen River. The tributary state succeeded in interpreting the idea of Qing superiority for its own purposes and in misleading the Qing officials during the survey process. Mu-ke-deng's investigation of Changbaishan was aimed at achieving a seamless and clearly demarcated line between the Qing and Chosŏn territories, but what it ended up creating between them was a borderland. The two countries were willing to tolerate this borderland as long as the tributary relationship was not challenged.

\section{SHARED SYMBOL, SEPARATE BOUNDARIES}

The investigation of 1712 served to promote further the connection of the Qing imperial court to Changbaishan. The Kangxi emperor's grandson, Qianlong, followed in his grandfather's footsteps by making homage to Shengjing (M. Mukden) a part of the imperial eastern tours. In 1743, after his first visit to the northeast, Qianlong wrote the "Ode to Mukden" (Shengjing fu), a panegyric on the magnificence of Mukden. The emperor glorified the mountains: "Our Great Qing dynasty arose from origins in Changbaishan. Marvelous humors there gathered-it was a most resplendent and auspicious place." ${ }^{99}$ By drawing a direct connection between Mukden and Changbaishan, Qianlong sought to "rekindle Manchu ethnic pride and encourage the preservation of traditional customs" in the eighteenth century, a time when rapid acculturation, exemplified by the loss of the Manchu language and a decline in martial skills among the bannermen, threatened the basis of Manchu power. ${ }^{100}$ During the late years of his reign, Qianlong further stressed the inseparable link between his ancestors and the mountain in his Researches on Manchu Origins (Manzhou yuanliu kao), a 1783 imperial publication that reveals Qianlong's understanding of the history and culture of the Manchu people. In the very first chapter of Manzhou yuanliu kao, the emperor states that "the ancestors of the Jin imperial clan lived in the Wanyan territory, where the White Mountain and the Black River were located." He further explains that the Qing dynasty received the mandate of heaven and his ancestors 
were born with the blessing of the red fruit when the heavenly maiden Fekulen went to the Bulhūri Lake at Changbaishan. ${ }^{101}$ As Pamela Crossley points out, it is not very likely that the Aisin Gioro family originated in Changbaishan, but Qianlong surely wanted to incorporate his ancestors into the myths of the sacred mountain, since it had long been respected by many northeastern peoples. ${ }^{102}$ As such, throughout the eighteenth century Changbaishan was seen as the source and symbol of Qing imperial power.

The investigation of the mountain in 1712 became the genesis of significant cultural shifts in the Chosŏn that the Qing court would not necessarily have predicted or desired. First, it encouraged Koreans to take a greater interest in Paektusan. As noted earlier, prior to the eighteenth century, Koreans did not really think of Paektusan as part of Chosonn territory, although they believed that it constituted the peak of the geomantic hierarchy of mountain chains on the peninsula. This ambiguous understanding of Paektusan was transformed after the investigation of 1712 into a conviction that the mountain was actually situated on Chosŏn land. The joint survey of the mountain and the erection of the stone marker led the Koreans to believe that the Qing court recognized the land south of the Yalu and Tumen Rivers as Chosŏn territory and therefore that they should lay stronger claim to their territorial sovereignty. Not surprisingly, the Koreans' confidence in their territoriality was most obviously expressed in their increasing interest in Paektusan and the northern region.

In 1761, when the Chosŏn court sought to identify the major mountains in the country, the minister of the Board of Rites, Han Ingmo, proposed that Paektusan should be named the Northern Peak (K. Pugak), stating, "Our northern land was the birthplace of the dynasty. . . . There are no rivers or mountains that do not originate from Paektusan. This mountain is surely the origin of our country." ${ }^{103}$ Han's claim corresponded to the intentions of King Yŏngjo (r. 1724-76), who sought to promote his kingly power against bureaucracy by elevating the status of Paektusan and the royal homeland. In the same way that the Kangxi emperor took advantage of the eastern tours and sacrifices to Changbaishan to demonstrate his imperial power, Yŏngjo wanted to strengthen his royal authority through rites for Paektusan and his ancestral homeland. Unlike Qing court officials, however, the Chosŏn officials disagreed with their king. They argued that it was very difficult to offer sacrifice to such rough mountaintops near foreign territory (K. hogye), and in addition that it was inappropriate for the Chosŏn king, who was enfeoffed by the emperor, to perform rituals for a place outside his territory. ${ }^{104}$ This debate lasted four months without yielding a conclusion, and Yŏngjo had to wait another six years to raise the issue of making ritual offerings again.

In 1767 , the subject of offerings at Paektusan reemerged. This time, Yŏngjo insisted more firmly on offering sacrifices to the mountain. He even ordered senior 
court officials to read the Yongbi ŏchŏn'ga, the mythical account of the Chosŏn dynasty's origins in the Paektusan area-an order that emphasized his determination to uphold his power against the bureaucracy. However, his opponents were also persistent. The minister of the Board of Punishment, Hong Chunghyo, for one, disagreed with the idea of making offerings at Paektusan:

There has been a discussion that Paektusan is the summit of all the mountains in our country, and therefore it should be offered sacrifices. However, the Book of Rites [Liji] says that feudal lords should offer sacrifices to mountains and rivers within their territory. I do not know whether this mountain is within our territory. Mu-ke-deng had previously built a stone marker at the watershed and demarcated the boundary. The watershed is located a day trip's distance from Paektusan. Therefore, it is hard to say that [the mountain] is on our land. ${ }^{105}$

Hong's remarks show that, as late as the 176os, Chosŏn officials still believed that Paektusan did not lie in Korean territory. But this time Yŏngjo did not give in to the pressure of the bureaucrats:

The first chapter of the Yongbi ŏch'on'ga, which I had ordered you to read, says, "Our ancestors had their homeland in Kyŏnghŭng." This passage is obvious evidence that Paektusan is in our territory. Therefore, even if the mountain were not on our land, it should still be offered sacrifices in order to venerate [the origin of the royal family]. It goes without saying, then, that if it is in fact on our land, [it should certainly be offered sacrifices]. ${ }^{106}$

He then ordered his officials to perform sacrifices to Paektusan and to write a ritual address to it. The first official rite of the Chosŏn court for the mountain was finally offered in 1768 , when the mountain was formally named the Northern Peak. $^{107}$

The Chosŏn court's demonstrated interest in Paektusan extended to the northern region - a second change that the 1712 investigation inspired among the Koreans. The Chosŏn court had long believed that the upper region of the Yalu River, where four counties had been established and later closed, should remain uninhabited and closed off for the purpose of preventing trespassing. By the time of Yŏngjo's reign, however, discussions about developing the upstream areas of the Yalu River had resumed. Yŏngjo sympathized with the suggestion that people should be settled in the northern region, which would also help strengthen security, but the majority of the court officials shared the traditional assumption that the more people gather at the boundary, the more illegal crossings will happen. Therefore, the dominant position at the Chosŏn court was that the land near the Yalu and Tumen Rivers should remain empty in order to prevent trespassing and subsequent trouble with the Qing. ${ }^{108}$ This belief that an uninhabited buffer zone at the boundary would protect Korean territory from the Qing continued 
to prevail at the Chosŏn court until the very late nineteenth century, as seen in later chapters.

The idea of developing the land at the upper reaches of the Yalu River was brought up again during the reign of King Chŏngjo (r. 1777-180o). Nam Chaehŭng, a member of the local elite living in the northern region, argued in a lengthy proposal that it had been a terrible mistake to abandon the four counties near the Yalu River and the fertile land in the north:

In the Four Closed Counties ... the land is vast and fertile. The fields are even, the weather is moderate, and grain grows well, so that it is truly a paradise for a pleasant life. However, the land was occupied by Jurchen barbarians [K. Yŏjin yain] from the late Koryŏ to the early [Chosŏn] period, and therefore the four counties were abandoned and undeveloped. After the Qing arose, the barbarians [K. hoin] who had lived near the [Yalu] River all left. Afterward, for 140 to 150 years, the land north of the Yalu, as wide as one thousand $l i$, has been empty, with no trace of barbarians living there. It is such a pity that all our fertile land south of the river has been simply discarded. ${ }^{109}$

Interests in the northern region at this time were not, of course, the exclusive sphere of the monarch and the court, but became prevalent more broadly among the Korean literati. It was the Korean literati in the late eighteenth century, rather than the Chosŏn kings, who were most interested in the northern region, as well as the territorial limits of their country. Some of the scholars of the "practical studies" movement (K. Sirhak), including Yi Ik (1681-1763), Sin Kyŏngjun (1712-1781), and Hong Yangho (1724-1802), believed that the 1712 investigation and the established stone marker had set the boundary between the Qing and the Chosŏn, resulting in a substantial loss of territory for the Chosŏn. Their sense of territorial loss developed into a kind of irredentism based on the assumption that the Qing-Chosŏn boundary was in reality located not on the Tumen River but in a place farther to the north. Some argued that the boundary was the Heilongjiang; others insisted it lay seven hundred $l i$ north of the Tumen River. Even those who accepted the Tumen as the boundary still believed that the Chosŏn had lost several hundred li of land in the upper region of the Tumen through the investigation. In order to recover this lost territory, these scholars argued, the Chosŏn should strengthen its military defenses in the north, especially by reopening the Four Closed Counties near the upper Yalu and the Six Garrisons near the Tumen. ${ }^{110}$

Chŏng Yagyong (1762-1836) was one of the most notable figures among the Chosŏn scholars who argued for Korean territorial sovereignty in the north. In his An Investigation of Our Nation's Territory (K. Abang kangyŏkko), Chŏng claimed that the Chosŏn dynasty had ruled over its territory, which was distinct from that of China, since the late fourteenth century. For Chŏng, who believed that territoriality was the essence of a state, there was no more urgent matter than 
reclaiming the northern land. Neglecting the Yalu River and abandoning the Four Closed Counties, he argued, were terrible mistakes from a security standpoint. Chŏng hoped that the eighteenth-century Chosŏn kings would endeavor to protect their territory in the north just as their great fifteenth-century ancestors, who launched military expeditions to conquer the Jurchens and secure the Tumen River, had done. ${ }^{111}$

The Chosŏn court finally made the decision to develop the land near the Yalu River in 1793, when part of the Four Closed Counties was opened for settlement. Local officials in P'yŏngan Province recognized that population settlement and land reclamation were more efficient ways to achieve security than the stationing of military guards would have been. As new settlers were granted a three-year tax exemption and permission to collect ginseng, a growing number of people moved to the north. ${ }^{112}$ This population growth led the Chosŏn court to assign officials to govern local affairs, but not until $1823 .{ }^{113}$ Only in the early nineteenth century, then, did Paektusan and the Yalu and Tumen Rivers, having long been considered part of foreign territory outside of the Chosŏn realm, come to be fully incorporated into Korean administrative control. It thus took a century after the investigation of 1712 for the Chosŏn to begin to demand full sovereignty over its northern region.

Triggered by Korean trespassing and ginseng poaching, the 1712 investigation of Changbaishan demonstrates that the Qing court continuously sought to achieve two goals - the imposition of Qing superiority and the demarcation of the territorial boundary-in its relationship with the Chosŏn court. The nature of their conceptions and practice of territoriality and sovereignty, together with the tributary relationship, played a crucial role during the investigation. It was the Qing court, not the Chosŏn, who initiated the investigation of the mountain sitting between them. The Manchus gathered geographic information about their sacred birthplace, but the wish of the Qing emperor to establish a clear boundary with the Chosŏn was not fulfilled. Instead, he bequeathed to his successor a borderland, characterized by uncertainty regarding the location of the Tumen riverhead and the exact limits of Qing territory, both authorized and sanctioned by the tributary relationship. Unexpectedly, it was the Chosŏn court and the Korean people whose understanding of their territorial realm was profoundly inspired and transformed by the information generated by the survey. Whether this outcome was planned or unexpected, the joint mapping project helped to confirm to the Koreans that the areas south of the Yalu and Tumen Rivers lay within the Korean realm and to increase Korean interest in its previously neglected, or abandoned, northern region. The lengthy debates regarding the offering of sacrifices to Paektusan and the reopening of the Four Closed Counties demonstrate the transformation of the 
Chosŏn court's perception of the northern region from a foreign land to Korean territory. Ironically, the investigation of Changbaishan, which was begun as part of a Qing empire-building strategy and completed under the terms of the tributary relationship, eventually helped foster a sense of Korean territory distinct from the Qing empire. These two seemingly contradictory ideas-Chosŏn territorial sovereignty and Qing rulership over a tributary state-coexisted without much trouble until the late nineteenth century, as discussed in chapter 3. 


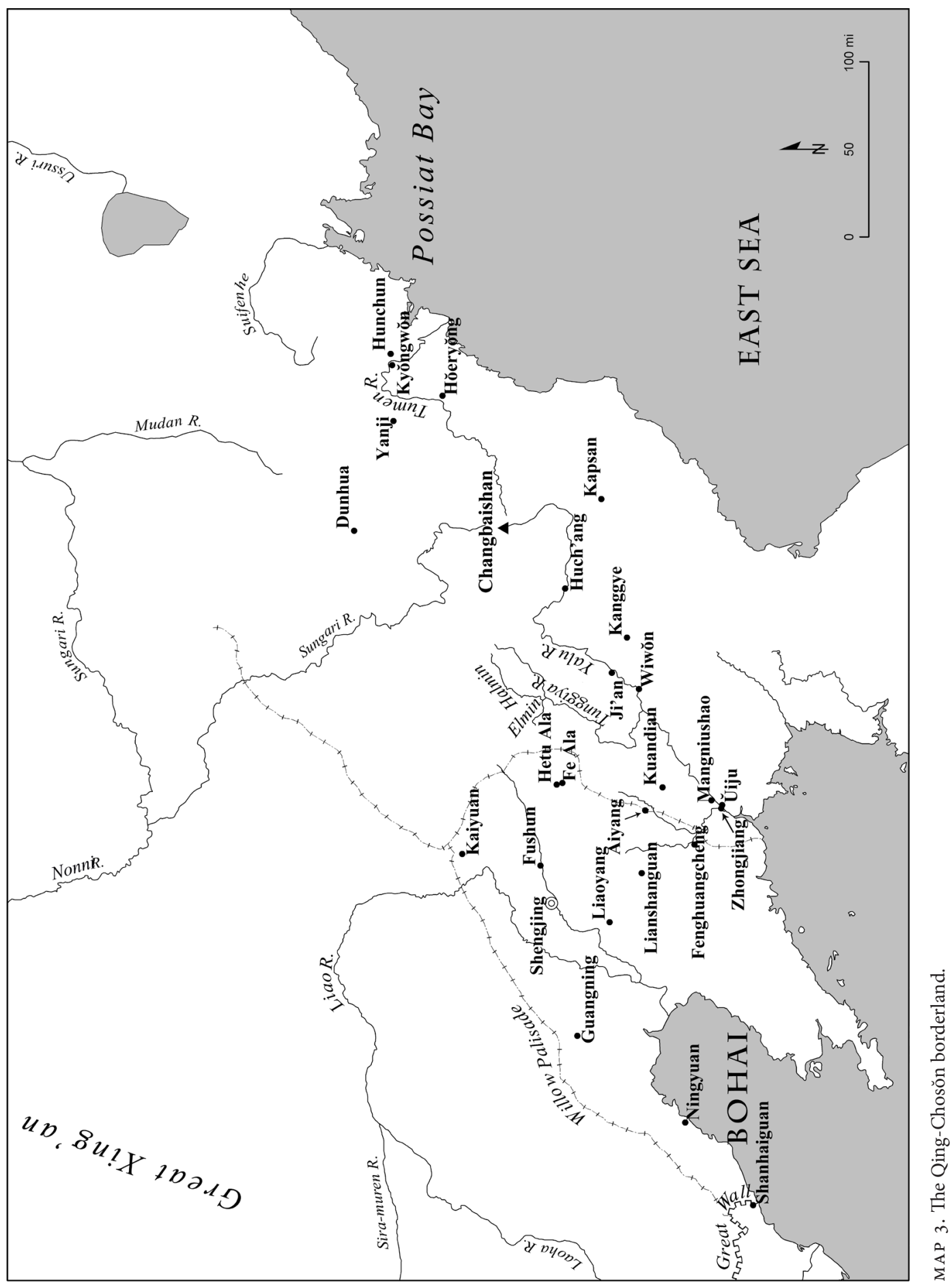

